\title{
Comparative Study of Carp Pituitary Gland (PG) Extract and Synthetic Hormone Ovaprim Used in the Induced Breeding of Stinging Catfish, Heteropneustes fossilis (Siluriformes: Heteropneustidae)
}

\author{
Md. Belal Hossain ${ }^{1,2}$, Md. Mosaddequr Rahman ${ }^{3}$, Md. Golam Sarwer ${ }^{4}$, Md. Yusuf $\mathrm{Ali}^{4}$, \\ Ferdous Ahamed ${ }^{5}$, Sharmeen Rahman ${ }^{3}$, Bernerd Fulanda ${ }^{6}$, Mohammad Mustafizur \\ Rahman $^{7}$, Bharat Raj Subba ${ }^{8}$, and Md. Yeamin Hossain, ${ }^{3, *}$ \\ ${ }^{1}$ Department of Fisheries and Marine Science, Noakhali Science and Technology University, Sonapur 3802, \\ Bangladesh \\ ${ }^{2}$ Biology Group, Faculty of Science, Univeristi Brunei Darussalam, Brunei BE1410 \\ ${ }^{3}$ Department of Fisheries, Faculty of Agriculture, University of Rajshahi, Rajshahi 6205, Bangladesh \\ ${ }^{4}$ Department of Aquaculture, Bangladesh Agricultural University, Mymensingh 2202, Bangladesh. \\ ${ }^{5}$ Faculty of Fisheries, Kagoshima University, 4-50-20 Shimoarata, Kagoshima 890-0056, Japan \\ ${ }^{6}$ Kenya Marine and Fisheries Research Institute, Marine and Coastal, P.O. Box 81651-80100, Mombasa, Kenya \\ ${ }^{7}$ Kulliyyah of Science, International Islamic University Malaysia, Jalan Istana, Bandar Indera Mahkota, 25200 \\ Kuantan, Pahang, Malaysia. \\ ${ }^{8}$ Department of Zoology, Post Graduate Campus (TU), Biratnagar, Nepal \\ Email: yeamin2222@yahoo.com
}

\begin{abstract}
The present study compared the effectiveness of the Carp pituitary gland extract (PGE) and the synthetic hormone Ovaprim on spawning success of the stinging catfish, Heteropneustes fossilis during induced breeding. The PGE hormone was administered at $6 \mathrm{mg} / \mathrm{kg}$ of body weight for females and $2 \mathrm{mg} / \mathrm{kg}$ of body weight for males. In contrast, Ovaprim was administered at $0.3 \mathrm{ml} / \mathrm{kg}$ body weight and $0.1 \mathrm{ml} / \mathrm{kg}$ of body weight for females and males, respectively. The spawning success was higher in the Ovaprim-induced individuals with better performance recorded at all stages of spawning including latency period, ovulation, fertilization, hatching and incubation period compared to the PGE-induced individuals. In the Ovaprim induced individuals, the latency period occurred within 10 hours while in PGinduced individuals, the latency was after 15 hours. Similarly, ovulation rate was $90 \%$ for Ovaprim injected fish but lower $78.7 \%$ for PGE injected fish. Higher rate of fertilization was observed in the eggs of Ovaprim treated fishes $86.7 \%$ compared to $69.2 \%$ in PGE induced fish. On the other hand, hatching rate was $76.9 \%$ in eggs spawned from Ovaprim induced individuals compared to $72.7 \%$ in PGE induced fish and the incubation period was also shorter at $3.5 \mathrm{~h}$ for eggs from Ovaprim-induced fish while the PGE induced fish eggs required a 5-h incubation period. Finally, the results showed that Ovaprim treated fish yielded better results compared the PGE treated fish in terms of ovulation, fertilization and hatching rates of $H$. fossilis.
\end{abstract}

Key words: Induced spawning; Heteropneustes fossilis; pituitary gland extract; ovaprim; ovulation rate; fertilization rate; hatching rate 
Md. Belal Hossain, Md. Mosaddequr Rahman, Md. Golam Sarwer, Md. Yusuf Ali, Ferdous Ahamed, Sharmeen Rahman, Bernerd Fulanda, Mohammad Mustafizur Rahman, Bharat Raj Subba, and Md. Yeamin Hossain / Our Nature (2012) 10: 89-95

\section{Introduction}

Fish and fisheries products are the third important foreign exchange earners for

Bangladesh and contribute $\sim 3.7 \%$ of the national GDP, $22.2 \%$ of agricultural GDP and $3.0 \%$ of the country's total export earning per annum (DoF, 2010). Furthermore, $58 \%$ of animal protein in the daily diet of Bangladeshi people is fish based and majority of the Bangladeshis consider fish and fish products as prime delicacy which is more preferred to other sources of protein. In the greater part of the $20^{\text {th }}$ century, Bangladesh had abundant capture fishery stocks and hence little interest was shown in culture techniques including the low cost extensive systems. However, improved harvesting techniques supported by better gear and vessels have witnessed the dwindling of the wild stocks with over-exploitation, habitat degradation, massive construction of flood control structures, abstraction of water for irrigation, intensive agriculture and development activities, pollution, destruction of mangrove forests all augmenting the already-poor state of the production from natural waters including rivers, floodplains, lakes and paddies. This is evidenced by the decline and subsequent reduction in the contribution of inland capture fisheries to the gross national fish production from $50 \%$ to $35 \%$. Furthermore, the marine capture fisheries production has remained static over the last 20 years (Mazid, 2002; Hoq, 2003; DoF, 2011). Nonetheless, during this period the aquaculture practices also picked up and have rapidly expanded over the recent years, because of increasing demand for fish and fishery products, adoption of improved aquaculture technologies and income generation. Consequently, contribution of aquaculture production in the national production increased gradually peaking during the 1995-2004 from $27 \%$ to $43 \%$ in 2004, respectively (DoF, 2005). The current aquaculture production is estimated at $46.6 \%$ of the total fish production as in the DoF 2009-2010 statistics (DoF, 2011).

The Stinging Catfish Heteropneutes fossilis (Bloch, 1974) (Heteropneustidae) is an economically important fish in Bangladesh. The $H$. fossilis, an important edible air sac catfish is a bimodal breather because it can respire aerially by gulping in air at various intervals when the oxygen content of water is low (Munshi, 1993). The species mainly inhabits ponds, ditches, swamps and marshes, but sometimes occurs in muddy rivers (Froese and Pauly, 2012). Due to its high market value, fast growth, tolerance to high stocking densities, ability to survive in oxygen-low waters (Dehadrai et al., 1985), and its low fat, high protein and iron content (Alok, et al., 1993), medicinal value (Froese and Pauly, 2012), H. fossilis is an ideal fish species for aquaculture (Vijayakumar et al., 1998; Haniffa and Sridhar, 2002).

However, the culture of $H$. fossilis requires constant supply of good quality fingerlings. Previously the major sources of fingerlings for aquaculture were mainly the capture fishery and other natural water bodies due to the limited capacity of the existing hatchery facilities to produce fish fingerlings. However, with increasing demand for better quality and quantity seed, the trend is reversing and is further driven by decreasing capture fishery fingerling 
Md. Belal Hossain, Md. Mosaddequr Rahman, Md. Golam Sarwer, Md. Yusuf Ali, Ferdous Ahamed, Sharmeen Rahman, Bernerd Fulanda, Mohammad Mustafizur Rahman, Bharat Raj Subba, and Md. Yeamin Hossain / Our Nature (2012) 10: 89-95

sources augmented by the declining environmental integrity and anthropogenic driven degradation of the natural water bodies. Furthermore, induced breeding techniques have continued to improve in Bangladesh and today, hatchery produced fry/fingerlings are the main sources of seed for the aquaculture industry in the country. Although, the production of fish seed from hatchery sources has increased dramatically, the quality has not improved owing to poor hatchery management practices leading to deleterious effects such as negative selection, inbreeding depression, indiscriminate interspecific hybridization among others.

A number of studies on the induced breeding of $H$. fossilis are available from literature and having been reviewed by several authors including spawning behavior (Kohil and Goswami, 1987), induced spawning (Alok et al., 1993; Haniffa et al., 2002), effects of Carp PGE doses on induced breeding (Begum et al., 2001), induced maturation and ovulation o (Nayak et al., 2001), induced spawning of catfish (H. fossilis) using human chorionic gonadotropin and synthetic hormone (Ovaprim) (Haniffa and Sridhar, 2002). However, detailed studies on the comparative effectiveness of Pituitary gland (PG) extracts and the synthetic hormone Ovaprim on the success of spawning in $H$. fossilis are clearly lacking in Bangladesh. Therefore, the present study compares the effectiveness of two agents (Ovaprim and PG extracts) in the spawning success of $H$. fossilis.

\section{Materials and methods}

\section{Study site and experimental design}

The present study was conducted at the Rakamary fish hatchery which is one of the leading hatcheries in Feni region of Bangladesh during February 2010 to July 2010.

\section{Brood Collection}

The brood fish for the artificial breeding of $H$. fossilis were obtained from the Rakamary fish hatchery. In this study, the male fish used ranged from 15 to $20 \mathrm{~cm}$ in total length and 30 to $70 \mathrm{~g}$ in weight. On the other hand, the female fish used ranged from 17 to $25 \mathrm{~cm}$ in total length and 40 to $150 \mathrm{~g}$ in weight. All the broodstock was checked for diseases and acclimatized before the induced breeding procedures and were kept separately in ponds of $14.3 \times 8.15$ $\times 1.5 \mathrm{~m}$ for four months before the start of the breeding season.

\section{Brood stock management}

The brood fish were fed on a supplementary diet formulated from $25 \%$ fish meal, $20 \%$ rice bran, $20 \%$ wheat flour, $15 \%$ mustard oil cake, $4 \%$ molasses and $1 \%$ vitamin premix. The brooders were reared for four months with feeding at two times a day at the rate of $5-6 \%$ of the body weight. Additionally, the ponds were treated with animal manure at 15 days interval at the rate of 1250 $\mathrm{kg}$ /hectare. Similarly, artificial fertilizer application was done using Urea and Triple Superphosphate (TSP) at the rate of 50 $\mathrm{kg} /$ hectare and $25 \mathrm{~kg} /$ hectare, respectively.

\section{Brood selection and conditioning}

Brooders were collected from the rearing ponds using a cast net in the morning between 8:00-9:00 am on the day of the 
Md. Belal Hossain, Md. Mosaddequr Rahman, Md. Golam Sarwer, Md. Yusuf Ali, Ferdous Ahamed, Sharmeen Rahman, Bernerd Fulanda, Mohammad Mustafizur Rahman, Bharat Raj

Subba, and Md. Yeamin Hossain / Our Nature (2012) 10: 89-95

breeding trials and immediately transferred to a circular tank in the hatchery. The males and females were kept in separate tanks and continuous water flow was maintained to ensure sufficient aeration. However, no feeding was conducted during the conditioning period.

\section{Brood stock injection and breeding induced}

Commercially available dehydrated Carp pituitary gland (PG) extracts and Ovaprim were used as inducing agents. The body weight $(\mathrm{g})$ of each brooder was weighed on an electronic balance (College B204-S, Switzerland) to estimate the required amount of PGE for the induction. The brooders were divided into groups of three females and five males of $H$. fossilis each, and then subjected to hormone treatment: one group was injected using PGE and the second group using Ovaprim hormone. The PGE hormone was administered at $6 \mathrm{mg} / \mathrm{kg}$ of body weight for females and $2 \mathrm{mg} / \mathrm{kg}$ of body weight for males. On the other hand, Ovaprim was administered at $0.3 \mathrm{ml} / \mathrm{kg}$ body weight and $0.1 \mathrm{ml} / \mathrm{kg}$ of body weight for females and males, respectively. For all treatments, the hormone was administered by intra-muscular injection on muscles beneath the dorsal fin slightly above the lateral line. After injection, the brooders were kept in separate breeding tanks for each treatment.

\section{Breeding and eggs transfer for incubation}

After injection, all the brooders were found to be ovulated after a period of 8-15 h. The brooders were then transferred from the holding tanks after the completion of ovulation. The fertilized eggs transferred into mini rectangular hatching trays while taking precaution to avoid damage and fungal/bacterial contamination during the egg collection process. The number of eggs released into each tray was estimated using gravimetric methods adapted from Legender (1986) and reviewed by Lagler (1992). Thereafter, a continuous flow of water was maintained for aeration to ensure the environmental conditions were optimal for the hatching process.

\section{Determination of ovulation, fertilization and hatching rate}

Ovulation rate, fertilization rate and hatching rates were calculated using the following formula:

Ovulation rate $(\%)=$ No. of fish ovulated $/$

Total no. of fish injected $\times 100$

Fertilization rate $(\%)=$ No. of fertilized eggs/ Total no. of eggs $\times 100$

Hatching rate $(\%)=$ No. of eggs hatched/ Total no. of fertilized eggs $\times 100$

\section{Statistical analyses}

Data and statistical analyses were performed using GraphPad Prism 5 software. A Chisquare test was used to check the ovulation, fertilization and hatching rates between Ovaprim and PGE treated fishes. All statistical analyses were considered significant at $5 \%(\mathrm{p}<0.05)$.

\section{Results and discussion}

\section{Ovulation rates}

There was no significant difference between ovulation rates in both males and females of $H$. fossilis within the treatments using the PGE and Ovaprim hormones. However, a 
Md. Belal Hossain, Md. Mosaddequr Rahman, Md. Golam Sarwer, Md. Yusuf Ali, Ferdous Ahamed, Sharmeen Rahman, Bernerd Fulanda, Mohammad Mustafizur Rahman, Bharat Raj Subba, and Md. Yeamin Hossain / Our Nature (2012) 10: 89-95

significant difference was found in ovulation rate between the treatment groups: ovulation rates were higher $(90 \%)$ in the Ovaprim treatment compared to ovulation rates of $78.7 \%$ registered in the PGE treated fishes (Table 1). Similar observations were recorded by Begum et al. (2001) who found that ovulation rates in $H$. fossilis injected with PGE at $75 \mathrm{mg} / \mathrm{kg}$ body weight were slightly lower although they recorded $90 \%$ ovulation when the fish were treated with PGE at $100 \mathrm{mg} / \mathrm{kg}$ body weight. Haniffa and Sridhar (2002) noted that very high doses of PGE hormone often resulted in higher rates of ovulation in the $H$. fossils. However, the latency period was significantly shorter in Ovaprim treated fish as opposed to PGE injected brooders (Table 1). On the contrary, Haniffa and Sridhar (2002) recorded a much longer ovulation period (18-24 h) when using Ovaprim at the same rate as in the present study whereas Kohil and Goswami (1987) reported a latency period 22-25 h. These earlier studies show a much longer latency period unlike that recorded in the present study. However, it is difficult to clearly spell out the causative factors for the observed differences. Gheyas et al. (2002) notes that a consortium of factors are likely to influence biological experiments particularly those involving hormones thus leading to differences in the observed latency periods.

\section{Fertilization rates}

Significantly higher fertilization rates $(86.7 \%)$ was recorded in eggs of the Ovaprim treated brooders compared to $69.2 \%$ fertilization rates in PGE treated fish (Table 1) confirming earlier studies which showed that the rate of fertilization is generally higher with Ovaprim treatments (Nandeesha et al., 1990; More et al., 2010). However, Haniffa and Sridhar (2002) recorded the fertilization rate of $H$. fossilis treated with Ovaprim at $0.3 \mathrm{ml} / \mathrm{kg}$ body weight as $70 \%$. Moreover, Begum et al. (2001) found the highest rate of fertilization (98\%) in $H$. fossilis injected by PGE at 75 $\mathrm{mg} / \mathrm{kg}$ which is much higher than found in the present study of PGE injected fishes. Differences in the fertilization rate can be attributed to the huge differences of hormonal doses, size of the brood fish, seasonal variation (Gheyas et al., 2002; Haniffa and Sridhar, 2002; Nwokoye et al., 2007), environmental factors, water quality parameters (alkalinity, DO, pH, hardness) (Khan et al., 2006). The quality of the PGE hormone cannot also be ruled out as factor influencing the fertilization rates.

\section{Hatching rates}

Both Ovaprim and PGE hormones were found to be equally effective for hatching success. However, the hatching rates were found to be slightly higher (76.9\%) for eggs in the Ovaprim treated fish compared to $72.7 \%$ in PGE treated fish. Moreover, the incubation period for eggs in the PGE treated fish was more than $1.5 \mathrm{~h}$ longer than the Ovaprim treated fish. Nayak et al. (2001) reported a hatching period of 10-12 h in $H$. fossilis treated with Ovaprim treatment at $27 \pm 1^{\circ} \mathrm{c}$ and obtained higher hatching rate of $96 \%$ using Ovaprim at the rate of 0.4 $\mathrm{ml} / \mathrm{kg}$ body weight. Haniffa and Sridhar (2002) reported a hatching rate $50.5 \%$ and $60 \%$ for $H$. fossilis injected with Ovaprim at a rate of $0.3 \mathrm{ml} / \mathrm{kg}$ and $0.5 \mathrm{ml} / \mathrm{kg}$ body weight, respectively. However, in terms of hatchling rate, Ovaprim treated fish yielded 
Md. Belal Hossain, Md. Mosaddequr Rahman, Md. Golam Sarwer, Md. Yusuf Ali, Ferdous Ahamed, Sharmeen Rahman, Bernerd Fulanda, Mohammad Mustafizur Rahman, Bharat Raj

Subba, and Md. Yeamin Hossain / Our Nature (2012) 10: 89-95

Table 1. Showing details of induced breeding in Stinging Catfish, Heteropneustes fossilis (Bloch, 1974) (Siluriformes: Heteropneustidae).

\begin{tabular}{lccccc}
\hline Inducing agent & $\begin{array}{c}\text { Latency } \\
\text { period (hrs) }\end{array}$ & Ovulation rate & $\begin{array}{c}\text { Fertilization } \\
\text { rate }\end{array}$ & Hatching rate & $\begin{array}{c}\text { Incubation } \\
\text { period (hrs) }\end{array}$ \\
\hline PG & 15 & $78.67 \%$ & $69.23 \%$ & $72.72 \%$ & 5 \\
Ovaprim & 10 & $90 \%$ & $86.67 \%$ & $76.92 \%$ & 3.5 \\
\hline
\end{tabular}

better results compared the PGE treated fish (Nandeesha et al., 1990; More et al., 2010).

\section{Conclusion}

The Ovaprim treated $(0.3 \mathrm{ml} / \mathrm{kg}$ body weight for females and $0.1 \mathrm{ml} / \mathrm{kg}$ of body weight for males) fish yielded better results compared the PGE treated $(6 \mathrm{mg} / \mathrm{kg}$ of body weight for females and $2 \mathrm{mg} / \mathrm{kg}$ of body weight for males) fish in terms of ovulation, fertilization and hatching rates of $H$. fossilis during this study. These results would be useful for apposite management of induced breeding in $H$. fossilis or any catfish.

\section{Acknowledgements}

We express our gratitude to (i) officers, operators and staff of the pond complex of Rakamary Fish Farm (Bangladesh) for their support during the present experiment and to all others who contributed to the success of the study and results, in one way or the other, we are really grateful.

\section{References}

Alok, D., T. Krishnan, G.P. Talwar and L.C. Garg 1993. Induced spawning of catfish, Heteropneustes fossilis (Bloch), using DLys ${ }^{6}$ salmon gonadotropin-releasing hormone analog. Aquaculture 115 (1-2): 159-167.

Begum, N., M.A. Rahaman, M.G. Hussain and M.A. Mazid 2001. "Effects of carp PG doses on induced breeding of shing, Heteropneustes fossilis (Bloch)". Bangladesh Journal Fisheries Research 5(2): 145-148.

Dehadrai, P.V., K.M. Yusuf and R.K. Das 1985. Package of practices for increasing production of air breathing fishes, p. 1-4. In: Aquaculture Extension Manual. Information and Extension Division of CIFRI (ICAR), India. New Series. No. 3.

DoF 2010. Matshya saptah sankalon (In Bengali), Department of Fisheries, Dhaka, Bangladesh. pp. 99.

DoF 2011. Jatiyo Matshya saptah sankalon (In Bengali), Department of Fisheries, Dhaka, Bangladesh. pp. 136.

DoF 2005. Fishery Statistical Year Book of Bangladesh 2003-2004. Department of Fisheries, Dhaka, Bangladesh.

Froese, R. and D. Pauly (Eds) 2012. Fishbase 2012. World Wide Web electronic publication. Available at: http://www.fishbase.org (Accessed on 23 June 2012).

Gheyas, A.A., M.S. Islam, M.F.A. Mollah and M.G. Hussain 2002. A comparative study on the embryonic development of gynogen, triploid, haploid and normal diploid of stinging catfish, Heteropneustes fossilis. Bangladesh Journal Fisheries Research 6(2): 107-115.

Haniffa, M.A.K. and S. Sridhar 2002. Induced spawning of spotted murrel (Channa punctatus) and catfish (Heteropneustes fossilis) using human chorionic gonadotropin and synthetic hormone (Ovaprim). Veterinarski Arhiv 72: 5156.

Hoq, M.E. 2003. Sustainable use of mangrove fisheries resources of Dundarbans, Bangladesh. Tropical Agricultural Research and Extension 6: 113-121.

Khan, A.M., H.A. Shakir, M. Ashraf and Z. Ahmad 2006. Induced spawning of Labeo rohita using 
Md. Belal Hossain, Md. Mosaddequr Rahman, Md. Golam Sarwer, Md. Yusuf Ali, Ferdous Ahamed, Sharmeen Rahman, Bernerd Fulanda, Mohammad Mustafizur Rahman, Bharat Raj Subba, and Md. Yeamin Hossain / Our Nature (2012) 10: 89-95

synthetic hormones. Punjab University Journal of Zoology 21 (1-2): 67-72.

Kohil, M.P.S. and U.C. Goswami 1987. Spwaning behaviour of a freshwater airbreathing Indian catfish Heteropneustes fossilis (Bloch). Matsya 12: $180-183$

Lagler, K.F. 1982. Freshwater Fishery Biology. WM.

C. Brown Company Publishers. Iowa, 2nd edn. pp. 108-109.

Legender, M. 1986. Seasonal changes in sexual maturity and fecundity and HCG induced breeding of the catfish Heteropneustes longifilis val. (Flarridae) reared in Ebrie lagoon (Ivory coast). Aquaculture 55: 201-213.

Mazid, M.A. 2002. Development of Fisheries in Bangladesh: Plans and Strategies for Income Generation and Poverty Alleviation. Momin Offset Press, Dhaka.

More, P.R., R.Y. Bhandare, S.E. Shinde, T.S. Pathan and D.L. Sonawane 2010. Comparative Study of synthetic hormones ovaprim and carp pituitary extract used in induced breeding of Indian major carps. Libyan Agriculture Research Center Journal Internation 1 (5): 288-295.

Munshi, J.S.D. 1993. Structure and function of the air breathing organs of Heteropneustes fossilis; in
Advances in fish research I (ed.) B R Singh (Delhi: Narendra Publishing House). pp. 99-138. Nandeesha, M.C., K.G. Rao, R. Jayanna, N.C. Parker, T.J. Varghese, P. Keshavanath and H.P.C. Shetty 1990. Induced spawning of Indian major carps through single application of Ovaprim C. pp. 581- 585. In: Hirano, R and L. Hanyu (Eds.). The second Asian Fisheries Forum, Asian Fisheries Society, Manila, Philiphines.

Nayak, P.K., T.K. Mishra, B.N. Singh, A.K. Pandey and R.C. Das 2001. Induced maturation and ovulation in Heteropneustes fossilis by using LHRHa pimozide and Ovaprim for production of quality eggs, and larvae. Indian Journal Fisheries 48(3): 269-275.

Nwokoye, C.O., L.A. Nwuba and J.E. Eyo 2007. Induced propagation of African clariid catfish, Heterobranchus bidorsalis (Geoffrey Saint Hillarie, 1809) using synthetic and homoplastic hormones. African Journal of Biotechnology 6 (23): 2687-2693.

Vijayakumar, C., S. Sridhar and M.A. Haniffa 1998. Low cost breeding and hatching techniques of the catfish (Heteropneustes fossilis) for smallscale farmers. Naga 21: 15-17. 